\title{
Electricity Production from Organic Wastes Fermentation by Microbial Fuel Cell Process
}

\author{
Piyarut Moonsri ${ }^{1, a^{*}}$, Wilaiporn Pongpian ${ }^{1, b}$, Prayak Juantrong ${ }^{2}$ \\ ${ }^{1}$ Department of Chemistry, Faculty of Science, Phetchabun Rajabhat University, \\ Phetchabun 67000, Thailand. \\ ${ }^{2}$ Khao Kho Learning Center Sufficiency and Renewable Energy, Phetchabun 67000, Thailand. \\ a*piyarutto@hotmail.com, batom2141@gmail.com
}

\section{Keywords: Electricity Production; Microbial Fuel Cell; Organic Waste}

\begin{abstract}
This research studied the electricity production from organic wastes fermentation by microbial fuel cell by using a single chamber microbial fuel cell (SCMFC). Two sizes (1 L and $10 \mathrm{~L}$ ) of simple SCMFC were fabricated by using a cylindrical plastic tank which anode compartment and cathode compartment separated by plastic plate with hole and covered with cotton fabric. The anode electrode contacted with organic matter and microorganisms where anaerobic reaction occurred to generate electron and proton. The electrons transferred through an external circuit while the protons diffused through the solution to the cathode electrode for reducing oxygen to water. From the study of the effective of different type of electrodes (carbon graphite rod, zinc metal, and copper metal) to the electricity generation using the SCMFC size $1 \mathrm{~L}$ in the fermentation of the synthetic sweetness solution (22\%Brix) with the effective microorganism (EM) for 36 hrs, it found that the fuel cell which used copper metal as electrode produced electricity increasing over times and has more efficient than the other electrode types. In the study of electricity generation from organic waste fermentation by using the SCMFC size $10 \mathrm{~L}$ and using copper metal as electrode, the results showed that the SCMFC with pineapple waste fermentation produced the current density, potential density, and power density higher than the fermentation of bananas and the fermentation of food garbage with EM. An optimal period of time for the production of electricity from this microbial fuel cell is the first five days of fermentation that the cells has voltage $\approx 500 \mathrm{mV}$, the current density $25.52 \mathrm{~mA} \mathrm{~m}^{-2}$, potential density $104.69 \mathrm{~V} \mathrm{~m}^{-2}$ and power density $12.59 \mathrm{~mW} \mathrm{~m}^{-2}$, and then decline over time five days $(120 \mathrm{hrs})$. Moreover the liquid fertilizer and the residues from the fermentation can be further used in agricultural because of the nutrient content $(\mathrm{N}$, $\mathrm{P}, \mathrm{K})$, organic carbon and organic material available.
\end{abstract}

\section{Introduction}

The major part of all energy consumed for electrical production in most parts of the world comes from fossil sources such as petroleum, coal and natural gas. These non-renewable sources will be exhausted in near future. Moreover, transformation of these fossil sources to electricity is made via combustion process that causes of green house gases liberation. Thus, the search for alternative sources of renewable energy and sustainable energy for electrical energy production has gained importance [1]. A micro fuel cell (MFC) is a device that converts biochemical energy into electrical energy via the catalytic reaction of microorganisms. Electricity generation from the MFC using anaerobic microbes is a recently technology with great potential for alternative green energy generation and environmental friendly. The MFC advantages over the technologies which used for generating energy from organic matter such as the direct conversion of organic substrate energy to electricity, operation at ambient temperature, not require gas treatment (only $\mathrm{CO}_{2}$ emission), do not need energy input, and widespread application in location lacking electrical infrastructures [2]. A lot of organic substances are degraded by micro-organisms through anaerobic metabolism liberating electrons and protons in a biochemical cell using anode and cathode separated by ion exchange membrane. The electric current is generated through the flow of electrons via a complete electric circuit [3]. The microbes in the anode compartment oxidize organic substances generating electrons 
and proton as equation (1). Then electrons are transferred to the cathode compartment through the circuit and the proton through the membrane. At the cathode compartment, electrons and protons are used in the reduction reaction (as equation 2) for reducing oxygen to water [4-5].

$$
\begin{aligned}
& \mathrm{C}_{6} \mathrm{H}_{12} \mathrm{O}_{6}+6 \mathrm{H}_{2} \mathrm{O} \longrightarrow 6 \mathrm{CO}_{2}+24 \mathrm{H}^{+}+24 \mathrm{e}^{-} \\
& 6 \mathrm{O}_{2}+24 \mathrm{H}^{+}+24 \mathrm{e}^{-} \longrightarrow 12 \mathrm{H}_{2} \mathrm{O}
\end{aligned}
$$

The MFC generally divided into two types of microbial fuel cells use a membrane (Membrane Microbial Fuel Cell, MMFC) and without a membrane (Membrane-less Microbial Fuel Cell, MLMFC). The microorganisms such as Shewanella putrefaciens, Geobacter sulfurreducens, Geobacter metallireducens and Rhodoferax ferrireducens show to generate electricity in the MFC without mediators by the electrochemically active redox enzymes on their outer membranes that transfer the electrons to the electrode without facilitate chemicals [6-7]. Several components of the MMFC are very expensive; ion exchange membrane and electrodes, also problems with strength on a large scale. Recently, a single chamber microbial fuel cell (SCMFC) has been developing to produce electricity by using single column reactor without both of ion exchanged membrane and mediators [8]. The SCMFC consists of column which divided of anode and cathode compartments without ion exchange membrane separation. At the anode part, the enrich microorganisms (the increasing number of infections microbial) is added into the organic waste to produce electron and proton by anaerobic reaction. Electrons are transferred through an external circuit while the protons diffuse through the solution to the cathode, where electrons combine with protons and oxygen to form water. The electrical producing potential of the SCMFC depends on several factors such as microorganism species, organic substances, operating condition, electrode metals, and carbon and nitrogen sources. Recently, the SCMFC technology is widely used in water treatment because not only waste water treatment but also generate electricity [8]. In Thailand, knowledge of organic waste fermentation to produce bio-fermented liquid for using in agriculture and health care have been created and developed by local wisdom scholars for long times ago. The simple equipments were used to construct the fermentation container similar to the SCMFC. The aims of this research were to study electricity generation from organic waste fermentation and properties of the fermentation by products.

\section{Material and Method}

Microbial Fuel Cell Fabrication. The SCMFC in this research was fabricated into two sizes for experimental. The first one was designed the chamber size volume $\approx 1 \mathrm{~L}$ for study the factor of electrode metal types $(\mathrm{C}, \mathrm{Zn}$, and $\mathrm{Cu})$ to electricity generation by the SCMFC. The second chamber was designed size volume $\approx 10 \mathrm{~L}$ for study the formula fermentation to electricity generation and some properties of the bio fermented water and the fermented solid waste from the SCMFC. Both of them were designed by a similar manner as shown in Fig.1

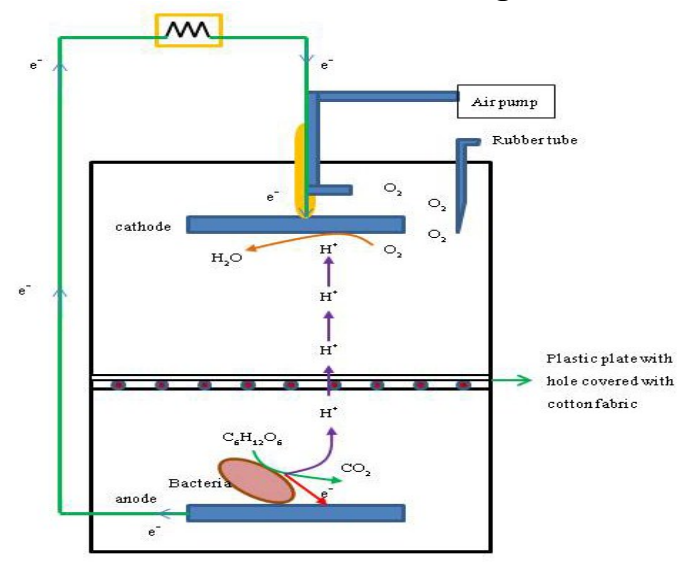

Fig. 1 Representation a simply construction and working principle of the fabricated SCMFC 
The SCMFC was fabricated simply by using a cylindrical plastic tank. The anode compartment and the cathode compartment was separated by using plastic plate with hole and covered with cotton fabric. At the bottom part, the anode electrode contacted with organic matter and microorganisms that electrons and protons were produced via anaerobic reaction. Electrons transferred through an external circuit while the protons diffused through the solution to the cathode electrode at the upper part, where oxygen gas from air was filled to combine with protons and electron to form water. The generated currents and the electrode potential were recorded by digital multimeter (model UT61B, Guangdon, China).

Chemical and Fermentation formula. The synthesis solution with the sweetness $22 \%$ Brix was prepared by mixing $250 \mathrm{~mL}$ of coconut juice with cane sugar $100 \mathrm{~g}$ and water to give $500 \mathrm{~mL}$ of the mixed solution. The bio fermented water from fruit was prepared by mixing $3 \mathrm{~kg}$ of ripe fruit with $1 \mathrm{~kg}$ of cane sugar. The bio fermented water from bamboo shoot was prepared by mixing $3 \mathrm{~kg}$ of bamboo shoot with $1 \mathrm{~kg}$ of molasses and $5 \mathrm{~L}$ of water. The bio fermented water from organic waste (garbage) was prepared by mixing $3 \mathrm{~kg}$ of organic waste with $1 \mathrm{~kg}$ of molasses and $5 \mathrm{~L}$ of water. Microorganisms used in this study were a natural microbial and an effective microorganism (EM) which purchased from the EMRO-Asia company (the EM composed of 3 microbial groups; lactic acid microorganism, yeast, and photosynthetic bacteria). In cases of fermentation with microbial, the microbial was added into the mixed solution by using $0.5 \mathrm{~kg}$.

The study of different electrode types to the electricity generation. This experimental was studied by the simply microbial fuel cell set (total volume $1 \mathrm{~L}$ ) by using plastic containers and air pump as shown in figure 2. The plastic container bottom was used for containing a synthetic sweetener solution volume $500 \mathrm{~mL}$, a microbe, and the anode electrode. The plastic container above, its bottom was made small holes distribute around the area and cover with a cellulose membrane (dialysis membrane) and cotton fabric. This container was used for containing distilled water volume $500 \mathrm{~mL}$ and the cathode electrode and at the top of this container was made two small holes for oxygen as filling (by air pumps) and for gases venting. The carbon graphite rod, zinc metal, and copper metal were using as electrodes in electrochemical cells. The anode electrode and the cathode electrode terminals were separated by about $10 \mathrm{~cm}$. The copper wires (long $55 \mathrm{~cm}$ ) used for connecting the circuit between the electrodes through the digital multimeter to read.

The study of electricity production via organic waste fermentation. This step has manufactured a microbial fuel cell which expanding the quantity and size of containers used to ferment $10 \mathrm{~L}$. In the oxidation reaction (anode), a copper rod inserted into the material for fermentation mash with brown sugar or molasses and microorganisms, the reduction reaction (the polar caps dial) was a copper rod immersed in a water tank inside the container. The copper rods, each with a radius of $5 \mathrm{~mm}$ and has a surface area of approximately $4,714 \mathrm{~mm}^{2}$ used in the reaction. The bipolar electrodes were separated by about $10 \mathrm{~cm}$, about $70 \mathrm{~cm}$ long copper wires connecting the circuit between the electrodes through the multimeter to read. Studying of the microbial fuel cells performance was carried out by using three formula of fermentation;

Formula 1: Fermentation of pineapple waste

Formula 2: Fermentation of bananas waste

Formula 3: Fermentation of food garbage + EM

The study of bio fermented fertilizer and solid waste properties investigation. The $\mathrm{pH}$ and conductivity of the liquid fertilizer were analyzed by using pH-Conductivity meter (GC700, EUTECH Singapore). In addition the nutrient content $(\mathrm{N}, \mathrm{P}, \mathrm{K})$ percent of organic carbon $(\% \mathrm{OC})$ percent of organic material $(\% \mathrm{OM})$ and carbon nitrogen ratio $(\mathrm{C} / \mathrm{N}$ ratio $)$ of the liquid organic fertilizer and residues material were also determined. For total nitrogen content determination $(\% \mathrm{~N})$ was analyzed according to the Kjeldahl method which consisted of digestion step by using sulfuric acid, distillation step, and titration step by using hydrochloric acid then the percent of total nitrogen was calculated. The total phosphorus content determination $(\% \mathrm{P})$ was analyzed according to the spectrophotometric molybdovanadophosphate method. This method, the sample was digested in the mixing solution of $\mathrm{HClO}_{4}$ : $\mathrm{HNO}_{3}$ then it was formed color the vanadomolydate reagent. The resulting complexe substance (yellow color solution) was determined phosphate content by using UV-Vis sphectrophotometer (model UV-1700, Simadzu Japan) at $420 \mathrm{~nm}$ and compared with a 
standard solution of phosphorus. The total potassium content determination $(\% \mathrm{~K})$ was analyzed flame photometric method. The sample was digested as same as the phosphate content dermination. Then the sample solution was determined potassium content by using atomic absorption spectrometer (model 3110, Perkin Elmer USA) at $766 \mathrm{~nm}$ [9]. The OC, OM, and C/N ratio were analyzed as follows: weighed 0.3-0.5 grams of sample a $250 \mathrm{ml}$ Erlenmeyer flask and added $10 \mathrm{~mL}$ of $1 \mathrm{~N}$ potassium dichromate solution, $10 \mathrm{~mL}$ of $98 \% \mathrm{H}_{2} \mathrm{SO}_{4}$, and $0.5 \mathrm{~mL}$ of o-phenanthroline ferrous sulfate into the mixed solution. Then the mixed solution was titrated with $0.5 \mathrm{~N}$ of ferrous sulfate until the end point of titration (the color of solution change from green color to brown-red color). From the weigh (m) of sample ( $\mathrm{g})$, the volume $(\mathrm{V})$ of $\mathrm{FeSO}_{4}$ in titration $(\mathrm{mL})$ and the ratio of $\mathrm{K}_{2} \mathrm{Cr}_{2} \mathrm{O}_{7}$ volume (mL) to the $\mathrm{FeSO}_{4}$ volume $(\mathrm{mL})$ for the titration with $\mathrm{K}_{2} \mathrm{Cr}_{2} \mathrm{O}_{7}$ in the blank which represented by $\mathrm{B}$ value then the The $\% \mathrm{OC}, \% \mathrm{OM}$, and $\mathrm{C} / \mathrm{N}$ ratio was calculated by following equations;

$$
\begin{aligned}
& \% \mathrm{OC}=\frac{0.3896 \times[\mathrm{B} \times \mathrm{V}]-10}{\mathrm{~m}} \\
& \% \mathrm{OM}=\% \mathrm{OC} \times 1.7241 \\
& \mathrm{C} / \mathrm{N}=\% \mathrm{OC} \times \% \mathrm{~N}
\end{aligned}
$$

\section{Results and Discussion}

The effectiveness of different electrode types to electricity generation. The simply microbial fuel cell set used in this study as shown in Figure 2. The resistance of the completed circuit on the integrated electrodes of carbon, zinc and copper electrodes were $27 \mathrm{k} \Omega, 12 \mathrm{k} \Omega$ and $6 \mathrm{k} \Omega$, respectively.
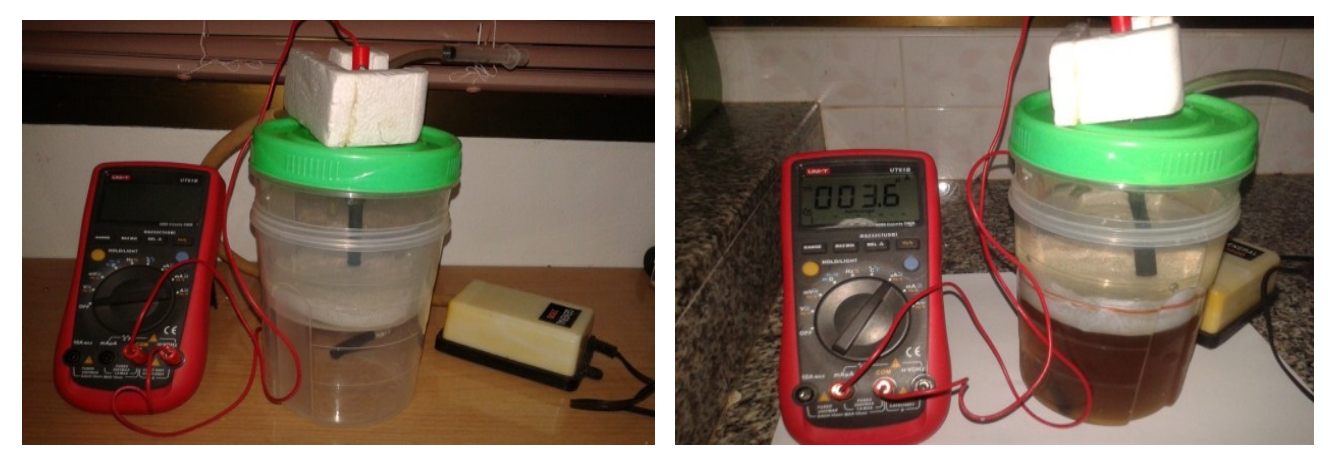

Fig.2 Representation a simply designed the SCMFC sets

From the performance of microbial fuel cell using a mild coconut mixed with sugar (sucrose) to give a sweetness about $22 \%$ Brix (concentrated solution of sucrose, about $20 \% \mathrm{wt} / \mathrm{v}$ ), the mixed sweetener solution have a $\mathrm{pH}$ of 6.08 with conductivity $19.22 \mathrm{mS}$. The electric current, potential, current density, potential density, and power density of each electrodes as shown in Table 1 and Table 2.

Table 1 Represent electric current (I) and potential (V) of the cell as a function of times (hrs)

\begin{tabular}{|c|c|c|c|c|c|c|}
\hline \multirow{2}{*}{ times $(\mathrm{hrs})$} & \multicolumn{2}{|c|}{ Carbon electrode } & \multicolumn{2}{c|}{ Zinc electrode } & \multicolumn{2}{c|}{ Copper electrode } \\
\cline { 2 - 6 } & $\mathrm{I}(\mu \mathrm{A})$ & $\mathrm{V}(\mathrm{mV})$ & $\mathrm{I}(\mu \mathrm{A})$ & $\mathrm{V}(\mathrm{mV})$ & $\mathrm{I}(\mu \mathrm{A})$ & $\mathrm{V}(\mathrm{mV})$ \\
\hline 3 & 1.3 & 35.8 & 8.7 & 113.6 & 22.8 & 136.8 \\
\hline 6 & 1.9 & 52.1 & 12.8 & 163.8 & 25.8 & 149.6 \\
\hline 9 & 2.2 & 60.5 & 18.3 & 238.2 & 27.6 & 162.8 \\
\hline 12 & 2.8 & 76.7 & 21.6 & 267.8 & 29.4 & 189.2 \\
\hline 18 & 3.6 & 101.7 & 29.2 & 358.4 & 31.8 & 198.8 \\
\hline 24 & 5.6 & 152.3 & 32.8 & 403.6 & 35.5 & 223.6 \\
\hline 30 & 7.2 & 189.6 & 38.8 & 427.7 & 48.5 & 335.8 \\
\hline 36 & 6.8 & 178.4 & 34.6 & 412.1 & 61.2 & 438.2 \\
\hline
\end{tabular}


Table 2 Represent current density, potential density, and power density of the cell as a function of times

\begin{tabular}{|c|c|c|c|c|c|c|c|c|c|}
\hline \multirow[b]{2}{*}{$\begin{array}{c}\text { times } \\
\text { (hrs) }\end{array}$} & \multicolumn{3}{|c|}{ Carbon electrode } & \multicolumn{3}{|c|}{ Zinc electrode } & \multicolumn{3}{|c|}{ Copper electrode } \\
\hline & $\begin{array}{c}\mathrm{I} \\
\text { density } \\
\left(\mathrm{mA} \mathrm{m}^{-2}\right)\end{array}$ & $\begin{array}{l}\mathrm{V} \text { density } \\
\left(\mathrm{V} \mathrm{m}^{-2}\right)\end{array}$ & $\begin{array}{l}\text { P density } \\
\left(\mathrm{mWm}^{-2}\right)\end{array}$ & $\begin{array}{c}\mathrm{I} \\
\text { density } \\
\left(\mathrm{mA} \mathrm{m}^{-2}\right) \\
\end{array}$ & $\begin{array}{l}\mathrm{V} \text { density } \\
\left(\mathrm{V} \mathrm{m}^{-2}\right)\end{array}$ & $\begin{array}{l}\text { P density } \\
\left(\mathrm{mWm}^{-2}\right)\end{array}$ & $\begin{array}{c}\mathrm{I} \\
\text { density } \\
\left(\mathrm{mA} \mathrm{m}^{-2}\right)\end{array}$ & $\begin{array}{c}\text { V density } \\
\left(\mathrm{V} \mathrm{m}^{-2}\right)\end{array}$ & $\begin{array}{c}\mathrm{P} \\
\text { density } \\
\left(\mathrm{mWm}^{-2}\right) \\
\end{array}$ \\
\hline 3 & 0.94 & 25.92 & 0.0337 & 2.18 & 28.40 & 0.2471 & 5.70 & 34.20 & 0.7798 \\
\hline 6 & 1.38 & 37.73 & 0.0717 & 3.20 & 40.95 & 0.5242 & 6.45 & 37.40 & 0.9649 \\
\hline 9 & 1.59 & 43.81 & 0.0964 & 4.58 & 59.55 & 1.0898 & 6.90 & 40.70 & 1.1233 \\
\hline 12 & 2.03 & 55.54 & 0.1555 & 5.40 & 66.95 & 1.4461 & 7.35 & 47.30 & 1.3906 \\
\hline 18 & 2.61 & 73.64 & 0.2651 & 7.30 & 89.60 & 2.6163 & 7.95 & 49.70 & 1.5805 \\
\hline 24 & 4.06 & 110.28 & 0.6176 & 8.20 & 100.90 & 3.3095 & 8.88 & 55.90 & 1.9845 \\
\hline 30 & 5.21 & 137.29 & 0.9885 & 9.70 & 106.93 & 4.1487 & 12.13 & 83.95 & 4.0716 \\
\hline 36 & 4.92 & 129.18 & 0.8784 & 8.65 & 103.03 & 3.5647 & 15.30 & 109.55 & 6.7045 \\
\hline
\end{tabular}

The results indicated that the microbial fuel cell which used carbon rods, galvanized sheet metal (zinc metal), and copper sheet metal as electrodes have the current density of the fuel cell of different electrodes (over times $30 \mathrm{hrs}$ ) equal $5.21 \mathrm{~mA} \mathrm{~m}^{-2}, 9.70 \mathrm{~mA} \mathrm{~m} \mathrm{~m}^{-2}$ and $12.13 \mathrm{~mA} \mathrm{~m}^{-2}$, respectively. After that, the current density of the fuel cells which used rods and galvanized sheet metal as electrode were decreasing. While as the fuel cell with copper sheet metal as electrode was increasing to $15.30 \mathrm{~mA} \mathrm{~m}^{-2}$. In addition it is possible in the same way as for the potential density is detected and the power density was calculated using copper as electrodes. Therefore microbial fuel cell in this study which used the copper metal as electrodes produced electricity increasing over times and has more efficient than using of carbon or zinc metal as electrodes.

Electricity production from organic waste fermentation. The results of the power and voltage of the fuel cells generated from three formulas organic waste fermentation (the mixture found sugar not more than $15 \%$ Brix) are shown in Table 3.

Table 3 Fuel cells performance to generate current potential and power from fermentation

\begin{tabular}{|c|c|c|c|c|c|}
\hline Formula/Day & $\begin{array}{c}\text { Current } \\
(\mu \mathrm{A})\end{array}$ & $\begin{array}{l}\text { Potential } \\
(\mathrm{mV})\end{array}$ & $\begin{array}{l}\text { Current density } \\
\qquad\left(\mathrm{mA} \mathrm{m}^{-2}\right)\end{array}$ & $\begin{array}{c}\text { Potential } \\
\text { density }\left(\mathrm{V} \mathrm{m}^{-2}\right)\end{array}$ & $\begin{array}{l}\text { Power density } \\
\qquad\left(\mathrm{mW} \mathrm{m}^{-2}\right)\end{array}$ \\
\hline \multicolumn{6}{|c|}{ Formula 1: Fermentation of pineapple waste } \\
\hline Day1 (24 hrs) & 65.3 & 250.2 & 13.85 & 53.08 & 3.47 \\
\hline Day3 (72 hrs) & 120.3 & 493.5 & 25.52 & 104.69 & 12.59 \\
\hline Day5 (120 hrs) & 98.8 & 375.8 & 20.96 & 79.72 & 7.88 \\
\hline \multicolumn{6}{|c|}{ Formula 2: Fermentation of bananas waste } \\
\hline Day1 (24 hrs) & 60.2 & 200.4 & 12.77 & 42.51 & 2.56 \\
\hline Day3 (72 hrs) & 112.7 & 465.1 & 23.91 & 98.66 & 11.12 \\
\hline Day5 (120 hrs) & 73.3 & 287.3 & 15.55 & 60.95 & 4.47 \\
\hline \multicolumn{6}{|c|}{ Formula 3: Fermentation of food garbage + EM } \\
\hline Day1 (24 hrs) & 45.4 & 150.3 & 9.63 & 31.88 & 1.45 \\
\hline Day3 (72 hrs) & 101.1 & 384.4 & 21.45 & 81.54 & 8.24 \\
\hline Day5 (120 hrs) & 63.1 & 244.5 & 13.39 & 51.87 & 3.27 \\
\hline
\end{tabular}

In this study, the microbial fuel cell generated electricity from the procedures of organic waste fermentation. The total resistance of the cell cycle electric power of approximately $4 \mathrm{k} \Omega$. Each of cells carried out by using pineapple fermentation and banana fermentation has the cell voltage of approximately $500 \mathrm{mV}$. As the duration of fermentation over three days $(72 \mathrm{hrs})$, the fuel cells prepared from pineapple fermentation has the current density of $25.52 \mathrm{~mA} \mathrm{~m}^{-2}$, potential density of $104.69 \mathrm{~V} \mathrm{~m}^{-2}$ and power density of $12.59 \mathrm{~mW} \mathrm{~m}^{-2}$, and then decline over time five days (120 hrs). This results similar to the cells which carried out with bananas waste fermentation and food garbage + EM fermentation. 
Properties of bio liquid fertilizer and solid residue investigation. After the fermentation had completed, the fermented liquid fertilizer and the residues were analyzed qualities. The results are shown in Table 4-5

Table 4 Physical properties, percent of fertilizer, percent of OC and $\mathrm{OM}$, and $\mathrm{C} / \mathrm{N}$ ratio in the fertilizer

\begin{tabular}{|c|c|c|c|c|c|c|c|c|}
\hline \multirow{2}{*}{$\begin{array}{c}\text { Fermentation } \\
\text { formula }\end{array}$} & $\mathrm{pH}$ of the & Solution & \multicolumn{3}{|c|}{ Percent of fertilizer } & \multicolumn{2}{|c|}{ Percent of } & $\mathrm{C} / \mathrm{N}$ \\
\cline { 5 - 7 } ratio \\
\hline Formula 1 & 3.77 & 17.81 & 0.25 & 0.04 & 1.35 & 1.47 & 2.52 & 5.88 \\
\hline Formula 2 & 3.81 & 15.62 & 0.25 & 0.03 & 1.73 & 1.46 & 2.52 & 5.84 \\
\hline Formula 3 & 4.03 & 13.16 & 0.25 & 0.12 & 3.08 & 8.96 & 15.41 & 35.84 \\
\hline
\end{tabular}

Table 5 Quantity of fertilizer, percent of $\mathrm{OC}$ and $\mathrm{OM}$, and $\mathrm{C} / \mathrm{N}$ ratio in the residues

\begin{tabular}{|l|c|c|c|c|c|c|}
\hline \multirow{2}{*}{$\begin{array}{c}\text { Fermentation } \\
\text { formula }\end{array}$} & \multicolumn{3}{|c|}{ Percent of fertilizer } & \multicolumn{2}{c|}{ Percent of } & \multirow{2}{*}{ C/N ratio } \\
\cline { 2 - 6 } & $\mathrm{N}$ & $\mathrm{P}$ & $\mathrm{K}$ & $\mathrm{OC}$ & $\mathrm{OM}$ & \\
\hline Formula 1 & 0.15 & 0.02 & 1.12 & 2.76 & 4.75 & 18.4 \\
\hline Formula 2 & 0.12 & 0.01 & 1.37 & 2.53 & 4.36 & 21.08 \\
\hline Formula 3 & 0.18 & 0.08 & 2.51 & 4.16 & 7.17 & 23.11 \\
\hline
\end{tabular}

\section{Conclusion}

In this study, the fabrication of simple microbial fuel cells can generate electricity. The design of the fuel cell is SCMFC via the redox reaction. It found that using of a copper metal electrode can generates the current density, potential density, and power density higher than the using of a carbon electrode and a zinc metal electrode. From the study on the operation of the fuel cell (size volume $10 \mathrm{~L}$ ) with using copper rod as electrodes, it found that the fermentation of fermented pineapple can produces the current density, potential density, and power density higher than the fermentation of bananas and the fermentation of food garbage with EM. A reasonable period of time for the production of electricity from this microbial fuel cell is the first five days of fermentation. Guidelines for use in microbial fuel cells as a source of electrical power can be made by individual cells connected in series to provide the voltage and power consumption increase for utilization. In addition, by-product from the production of electricity is fermented or bio-liquid fertilizer and residues waste left by the filter which can be further used in agriculture.

\section{Acknowledgement}

This work was subsidized by budgets of Phetchabun Rajabhat University which considered by the National Research Council of Thailand. Thank also to Faculty of Science and Technology, Phetchabun Rajabhat University for laboratory instruments support and facilitation in this study.

\section{References}

[1] A. Demirbas, Biodiesel production from vegetable oils via catalytic and non-catalytic supercritical methanol transesterification methods. Progress in Energy and Combustion Science. 31(2005) 466-87.

[2] A. S. Mathuriya, and V. N. Sharma, Bioelectricity production from paper industry waste using a mibcrobial fuel cell by Clostridium species. J. Biochem. Tech. 1(4) (2009) 163-168.

[3] A. Banik, N. K. Jana, B. R. Maiti, and T. K. Ghosh, Development of Microbial Fuel Cells and Electrode Designs with Waste Water Anaerobes. Greener J. Bio. Sci. 2(2) (2012) 13-19.

[4] D. R. Bond, and D. R. Lovley, Electricity Production by Geobacter sulfurreducens Attached to Electrodes. Appl. Env. Microbiol. 69(3) (2003) 1548-1555. 
[5] D. Madden, and J. Schollar, The Microbial Fuel Cell. Biosci. Explain. 1(1) (2001) 1-4.

[6] E. Katz, A. N. Shipway, and I. Willner, Handbook of Fuel Cells-Fundamentals, Technology and Applications. John Wiley and Sons.New York, 2003, pp. 1-27.

[7] D. R. Bond, and D. R. Lovley, Electricity production by Geobacter sulfurreducens attached to electrodes. Appl. Env. Microb. 69 (2003) 1548-1555.

[8] H. Liu, R. Ramnarayanan, and B. E. Logan, Production of electricity during wastewater treatment using a single chamber microbial fuel cell. Env. Sci. Tech. 38 (2004) 2281-2285.

[9] S. K Kathong, and C. Ruangviriyachai, Determination of Nitrogen, Phosphorus and Potassium in Liquid Organic Fertilizer. KKU. Res. J (GS). 14(4) (2014) 57-68. 